\title{
Influence of the Casein Composite Genotype on Milk Quality and Coagulation Properties in the Endangered Agerolese Cattle Breed
}

\author{
Sara Albarella ${ }^{1, *(\mathbb{D}}$, Maria Selvaggi ${ }^{2}$, Emanuele D'Anza ${ }^{1}$, Gianfranco Cosenza ${ }^{3}{ }^{\mathbb{D}}$, \\ Simonetta Caira ${ }^{4}$, Andrea Scaloni ${ }^{4}$, Annunziata Fontana ${ }^{5}$, Vincenzo Peretti ${ }^{1}$ and \\ Francesca Ciotola ${ }^{1}$ \\ 1 Department of Veterinary Medicine and Animal Production, University of Naples Federico II, via Delpino 1, \\ 80137 Naples, Italy; emanuele.danza@unina.it (E.D.); vincenzo.peretti@unina.it (V.P.); \\ francesca.ciotola@unina.it (F.C.); \\ 2 Department of Agricultural and Environmental Science, University of Bari Aldo Moro, 70126 Bari, Italy; \\ maria.selvaggi@uniba.it \\ 3 Department of Agriculture, University of Napoli Federico II, 80055 Portici, Italy; giacosen@unina.it \\ 4 Proteomics \& Mass Spectrometry Laboratory, ISPAAM, National Research Council, 80147 Naples, Italy; \\ simonetta.caira@ispaam.cnr.it (S.C.); andrea.scaloni@cnr.it (A.S.) \\ 5 Laboratory of milk analyses (LSL), Italian Breeders Association (AIA), 00054 Maccarese, Italy; fontana.t@aia.it \\ * Correspondence: sara.albarella@unina.it; Tel.: +39-081-2536502; Fax: +39-081-292981
}

Received: 16 April 2020; Accepted: 18 May 2020; Published: 20 May 2020

check for updates

Simple Summary: Characterization of variants in casein genes allows breeders and researchers to select the most suitable cows for milk production within the same breed. It has been observed that milk from different cattle breeds with the same casein composite genotype shows different chemical and coagulation properties. The aim of this work was to characterize CSN1S1, CSN2 and CSN3 gene variants in Agerolese cattle, an Italian autochthonous breed, milk of which is used to produce "Provolone del Monaco", a PDO cheese with a relevant economic interest for the Lattari Mountains area and the Sorrento Peninsula (Naples, Italy). According to the results, Agerolese cattle population shows a low genetic variability and a high prevalence of the $A^{2}$ allele of CSN2. As regard chemical composition and coagulation properties, $\mathrm{BBA}^{1} \mathrm{~A}^{2} \mathrm{AB}, \mathrm{BBA}^{2} \mathrm{~A}^{2} \mathrm{BB}$ and $\mathrm{BBA}^{2} \mathrm{~A}^{2} \mathrm{AB}$ composite genotypes showed the best parameters. These results will be used to promote the genetic value of Agerolese cattle and to help breeders to improve their breeding practice.

Abstract: The aim of this study was the characterization of CSN1S1, CSN2 and CSN3 genetic variability in Agerolese cattle, and the investigation of the effect of casein composite genotypes (CSN1S1, CSN2 and CSN3) on quality and coagulation traits of the corresponding milk. To these purposes, blood and milk from 84 cows were sampled and analysed. Allele frequencies at CSN2 and CSN3 revealed no Hardy-Weinberg equilibrium in the population with a prevalence of allele $\mathrm{A}^{2}$ for $C S N 2$ and allele $\mathrm{B}$ for $C S N 3$. $\mathrm{BBA}^{1} \mathrm{~A}^{2} \mathrm{AB}$ and $\mathrm{BBA}^{2} \mathrm{~A}^{2} \mathrm{AB}$ composite genotypes were the most common in the population. $\mathrm{BBA}^{1} \mathrm{~A}^{2} \mathrm{AB}$ showed a higher total solids and fat content $(12.70 \pm 0.16$ and $3.93 \pm 0.10$, respectively), while $\mathrm{BBA}^{2} \mathrm{~A}^{2} \mathrm{BB}$ showed the best coagulation properties (RCT $12.62 \pm 0.81$; $\mathrm{k}_{20} 5.84 \pm 0.37 ; \mathrm{a}_{30} 23.72 \pm 1.10$ ). Interestingly, the $\mathrm{A}^{2}$ allele of $C S N 2$ was very widespread in the population; thus, it will be intriguing to verify if $\mathrm{A}^{2} \mathrm{~A}^{2}$ Agerolese cattle milk and the derived cheese may have better nutraceutical characteristics.

Keywords: CSN1S1; CSN2; CSN3; Bos taurus; reological properties; milk traits 


\section{Introduction}

Agerolese cattle are a dual-purpose (dairy and beef) autochthonous breed reared in Southern Italy. It originated in the area of the Lattari Mountains and the Sorrento Peninsula (Naples, Italy) and underwent crossbreeding along successive generations with Bretonne, Brown Swiss, Jersey and Friesian breeds. It is a rustic breed that produces milk with excellent organoleptic characteristics, mainly destined to the production of the PDO (Protected Denomination of Origin) cheese (reg. CE no. 121/2010) "Provolone del Monaco". This is a fine pasta filata cheese that has a melon or pear shape without the head divided in six sides and that can weight from $2.5-8 \mathrm{~kg}$. The rind is yellow and almost smooth with inlets in correspondence of the cord used to hang it. The flavour is sweet and buttery with a spicy taste whose intensity depends on the length of seasoning which must be at least six months. A minimum of $20 \%$ of Agerolese milk must be used for its production [1]. "Provolone del Monaco" PDO cheese has become a driving force for the economy of the area occupying 30 breeders able to generate an annual turnover of 3 million euros. This has led to a renewed interest in reproducing this breed, thus preventing its extinction; to date there are 285 animals enrolled in the birth register (Italian Breeders Association-AIA). Nowadays, there is very little information about Agerolese cattle genetics, especially regarding the evolution of casein genes through the centuries as an effect of inbreeding. Selvaggi and coworkers observed an association between different genotypes at the SIRT1 g.-274C $>\mathrm{G}$ locus and milk production performances and reproductive traits [2]. In other studies, a positive effect of the TT genotype of STAT5A/Msl I locus on fat and protein content of milk was observed, while no variability at STAT5A/Ava I locus was found [3], despite the common origin with the Podolica breed that shows high genetic variability at this locus $[4,5]$. From a cytogenetic point of view, Agerolese cattle exhibited very stable genome, when compared with the other Italian cattle breeds [6], and low incidence of chromosomal abnormalities [7]. There is a lack of knowledge concerning genetic variability in loci directly involved in milk production and clotting properties in Agerolese breed.

The most studied milk proteins are $\alpha_{\mathrm{s} 1}-\mathrm{CN}, \beta-\mathrm{CN}$ and $\mathrm{k}-\mathrm{CN}$, which are encoded by CSN1S1, CSN2 and CSN3 genes, respectively. CSN1S1 locus shows nine alleles (A, B, C, D, E, F, G, H and I) that correspond to nine protein variants [7]. Only for the $G$ variant, a considerable reduction of $\alpha_{\mathrm{s} 1}$-casein content in the milk has been reported, with a consequently lower milk coagulation times and curd firmness [8]; due to the reduction in the milk coagulation proprieties (MCP), the presence of the G variant has a negative impact on dairy productions [9]. $\beta-\mathrm{CN}$ constitutes up to $45 \%$ of the casein and 12 genetic variants $\left(\mathrm{A}^{1}, \mathrm{~A}^{2}, \mathrm{~A}^{3}, \mathrm{~B}, \mathrm{C}, \mathrm{D}, \mathrm{E}, \mathrm{F}, \mathrm{G}, \mathrm{H}^{1}, \mathrm{H}^{2}\right.$ and $\left.\mathrm{I}\right)$ have been isolated and characterized, among which $A^{1}$ and $A^{2}$ are the most common [10]. $\beta$-casein variants play an important role in cheese yield and quality and their concentration is positively associated with good rennet properties of milk [11]. In particular, the CSN2 $B$ allele is associated with an increase of milk casein content and smaller casein micelle size $[12,13]$. The $\mathrm{k}-\mathrm{CN}$ proportion in milk and its variants, namely A or $\mathrm{B}$, are important because of their influence on clotting time, curd firming time and curd firmness $[14,15]$. In Bos genus the encoding gene, CSN3, is characterized by at least 14 alleles $\left(\mathrm{A}, \mathrm{A}^{\mathrm{I}}, \mathrm{B}, \mathrm{B}^{2}, \mathrm{C}, \mathrm{D}, \mathrm{E}, \mathrm{F}^{1}, \mathrm{~F}^{2}\right.$, $G^{1}, G^{2}, H$, I and J) coding 13 proteins and one synonymous $\left(A^{\mathrm{I}}\right)$. In particular, allele $B$ is associated with higher protein content, determines smaller average casein micelle sizes and better coagulating properties [16]. $\mathrm{k}-\mathrm{CN}$ is the milk component mainly influencing milk coagulation properties; in this context, it has been proven that the proportion of $\kappa$ - and $\alpha-\mathrm{CN}$ have positive effects on curd firming time and curd firmness [17]. Milk production traits and milk clotting properties (MCP) are relevant to the dairy industry as they relate to socio-economic factors affecting milk production. In order to evaluate MCP, three parameters have principally been used: rennet coagulation time (RCT, min), curd-firming rate $\left(\mathrm{k}_{20}, \mathrm{~min}\right)$ and curd firmness $\left(\mathrm{a}_{30}, \mathrm{~mm}\right)[16,18]$.

The effects of genetic variants of milk proteins on MCP have been thoroughly investigated in cattle; only in a few cases, the effect of polymorphisms at the casein gene cluster has been found to be associated with MCP. In order to manage and preserve endangered livestock breeds, the knowledge of their performances and genetic variability is essential. It is generally agreed that $B$ variants of $\beta-\mathrm{CN}$ and $\mathrm{k}-\mathrm{CN}$ favourably affect MCP by reducing coagulation time and improving curd firmness; on the 
other hand, $A$ and $E$ variants of $C S N 3$ have shown negative effect on milk clotting [18,19]. Moreover, the $\mathrm{A}^{1}$ variant of CSN2 improves rennet coagulation properties respect to $\mathrm{A}^{2}$ counterpart, [20], which has less influence on this technological property. Despite of several studies on the relation between MCP and genetic variants of CSN1S1, CSN2 and CSN3, the evaluation of the effect of a particular locus can be confounded by the other causal loci in the genome. For this reason, studies on the influence of genetic factors affecting coagulation parameters of milk from different cattle breeds were focused on casein locus composite genotype rather than single genes [21-23].

The objective of this study was to analyse the genetic variability of CSN1S1, CSN2 and CSN3 genes in the Agerolese cattle breed and to evaluate the effect of single casein gene polymorphism and of casein composite genotype on milk quality traits and milk coagulation properties (MCP).

\section{Materials and Methods}

\subsection{Ethical Statement}

The Ethical Animal Care and Use Committee of University of Naples Federico II pre-approved all procedures used in this research study (Prot. Nr. PG/2019/0104896).

\subsection{Samples}

Eighty-four Agerolese cows, enrolled in the Birth Register, and reared in 14 farms located in the production area of "Provolone del Monaco PDO" were involved in this study. All the animals received the same lactation diet according to the production disciplinary of "Provolone del Monaco PDO". Milk and blood samples were collected from each animal for the genetic characterization at CSN1S1, CSN2 and CSN3 genes. All the samples were stored at $4{ }^{\circ} \mathrm{C}$ until analysis. Individual milk samples $(50 \mathrm{~mL})$ from sixty-three cows at the same lactation stage (70 to $200 \mathrm{~d}$ postpartum) were collected in the morning, during the spring, to evaluate the effect of casein composite genotype on quality and coagulation properties (MCP). All the milk samples were transported refrigerated and stored at $4{ }^{\circ} \mathrm{C}$ until analysis.

\subsection{Genotyping by Ultra-Thin Layer Isoelectric Focusing on Polyacrylamide Gel (UTLIEF)}

Individual genotyping at CSN1S1 (A, B and C variants), CSN2 ( $\mathrm{A}^{1}$ and $\mathrm{A}^{2}$ variants), CSN3 (A, B and $C$ variants) was performed by Ultra-thin layer isoelectric focusing on polyacrylamide gel (UTLIEF). The isoelectrophoretic techniques is a recommended suitable analysis for routine typing of animals at the protein level. In a rapid, cheap and high-throughput way, it allows to detect $\alpha_{\mathrm{s} 1^{-},}, \beta$ - and $k$-casein variants in individual or bulk milk samples, thus defining the casein genetic variability present in the bovine population.

Individual whole bovine casein was prepared by acid precipitation of skim milk, followed by centrifugation at $2500 \times \mathrm{g}$ for $15 \mathrm{~min}$ [24]. The casein obtained was rinsed twice with distilled water to eliminate whey, then freeze-dried and stored at $-20^{\circ} \mathrm{C}$ before use. Individual casein samples from individual milks $(20 \mathrm{~g} / \mathrm{L})$ were dissolved in $9 \mathrm{M}$ urea solution containing 2-mercaptoethanol $(1 \mathrm{~mL} / \mathrm{L})$. UTLIEF was performed on a 2117 Multiphor II Apparatus (LKB, Bromma, Sweeden) at $10^{\circ} \mathrm{C}$ using a Multitemp II (LKB, Bromma, Sweeden). Homemade polyacrylamide gel $(265 \times 125 \times 0.25 \mathrm{~mm}$; $4.5 \% \mathrm{~T}$ and $0.3 \% \mathrm{C}$ ) consisted of $7.2 \mathrm{M}$ urea, $1 \%(w / v)$ glycerol and $1 \%(v / v)$, Ampholine (GE Healthcare Amersham Bioscience, Buckinghamshire, UK). To obtain the $\mathrm{pH}$ gradient 2.5-6.5 Ampholine 2.5-5, 4.5-5.4 and 4-6.5 in the ratio 1.6:1.4:1 (by vol) were mixed. TEMED and PER 0.04\% $(v / v)$ and $0.07 \%(w / v)$, respectively, were added to the gel, as activator and catalyst agents of polymerization. UTLIEF analysis consisted of three steps: pre-focusing set, $2000 \mathrm{~V}, 15 \mathrm{~mA}, 4 \mathrm{~W}, 30 \mathrm{~min}$; sample focusing set, $2000 \mathrm{~V}, 15$ $\mathrm{mA}, 4 \mathrm{~W}, 60 \mathrm{~min}$; final focusing set, $3000 \mathrm{~V}, 5 \mathrm{~mA}, 20 \mathrm{~W}, 130 \mathrm{~min}$. The gel was stained with Coomassie Brilliant Blue G-250 as described by Neuhoff et al. [25]. Agerolese cow's milk samples were analyzed together with other bovine casein counterparts containing homozygous alleles respectively for $\mathrm{A}^{1}$ and $\mathrm{A}^{2}$ of $\beta-\mathrm{CN}, \mathrm{A}$ and $\mathrm{B}$ of $\kappa-C N$, and $\mathrm{B}, \mathrm{C}$ and $\mathrm{A}$ of $\alpha_{\mathrm{s} 1}-\mathrm{CN}$ for their genetic classification based on protein 
isoelectric point values. Protein variant identification in the milk samples was made by comparison with standard that consisted of purified genetic variants from bovine milk (Supplementary Figure S1).

\subsection{Genotyping of CSN3 B Allele and CSN1S1 G Allele}

Since some electrophoretic profiles were unclear, a PCR-RFLP was performed to distinguish carriers

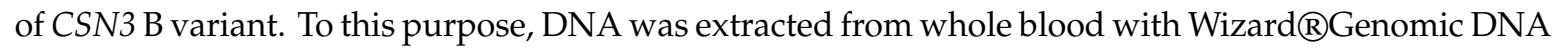
purification kit (Promega, Madison, WI, USA). The DNA regions of the bovine CSN3 gene spanning part of the exon 4 were amplified by iCycler (Bio-Rad, Hercules, CA, USA) using primers designed on the partial bovine genomic sequence (EMBL acc. no. X14908.1) as reported by Mitra et al. [26] (Table 1). PCR reaction mixture and thermal conditions were accomplished according to Ren et al. [27]. For genotyping, the digestion of $17 \mathrm{~mL}$ of each PCR amplification was accomplished with $10 \mathrm{U}$ of Hinf I endonuclease (Promega, Madison, WI, USA) for $5 \mathrm{~h}$ at $37^{\circ} \mathrm{C}$ following the supplier's directions for experimental conditions.

In order to detect carriers of CSN1S1 G allele, the DNA regions of the bovine CSN1S1 gene spanning exon 19 and flanking regions were amplified by means of PCR using primers designed on the complete bovine CSN1S1 genomic sequence (EMBL acc. no. X59856.2) (Supplementary Table S1). PCR reaction mixture and thermal conditions were accomplished using the method described by Rando et al. (1998) [28]. For both loci, all PCR amplifications were carried out using Bio-Rad T100 thermocycler (Bio-Rad, Hercules, CA, USA). PCR and digestion products were analysed directly by electrophoresis in 3\% TBE agarose gel (Bio-Rad, Hercules, CA, USA) in 0.5X TBE buffer and stained with SYBR ${ }^{\circledR}$ green nucleic acid stain (Lonza - Rockland - ME - USA).

\subsection{Milk Chemical Composition and MCP}

Milk chemical composition and coagulation properties were evaluated at the Laboratory of milk analyses of Italian Breeders Association (AIA). Milk samples were transported refrigerated $\left(4^{\circ} \mathrm{C}\right)$ and analysed within $12 \mathrm{~h}$ from collection. Total solids, solid-non-fat, fat, protein, casein, lactose, ash, RCT, $\mathrm{k}_{20}$, $\mathrm{a}_{30}$ were measured using MilkoScan FT 6000 milk analyzer (Foss Electric A/S, Hillerød, Denmark) according to ISO 9622 IDF 141C: 2013. MCPs were predicted using mid-infrared spectroscopy models developed by De Marchi et al. [29,30].

All samples had somatic cell count (SCC) below 500,000 cells/mL $(269,000 \pm 210,000)$.

\subsection{Statistical Analysis}

Correlation among composite genotypes, chemical composition and MCP values of milk were performed only for composite genotypes with a minimum of nine animals. Allele frequencies were calculated by simple allele counting [31]. Possible deviations of genotypic frequencies from expectations under Hardy-Weinberg equilibrium were tested by a chi-square test. Some population genetic indices, such as: gene heterozygosity $(\mathrm{He})$, gene homozygosity $(\mathrm{Ho})$, effective allele numbers $(\mathrm{Ne})$ and Fixation Index (FIS) were performed by POPGENE32 software version 1.32 [32]. Finally, polymorphism information content (PIC) was calculated according to Botstein et al. [33]. The variables of this study were numeric and continuous. All production data were tested for normality and homoscedasticity. Normality test were applied using Shapiro-Wilk criterion [34]. All the considered variables did not deviate from a normal distribution $(p>0.05)$. Moreover, homoscedasticity was tested with Levene's Test [35] that evidenced a homoscedastic distribution of data $(p>0.05)$. A statistical analysis was carried out to estimate the effect of single $\alpha$ s1- $\beta$ - and k-casein genotypes and composite genotypes on milk composition traits and MCP. The GLM procedure, implemented with SAS software (Ver. 9.2) [36], included the single loci genotypes, the composite genotype and the parity (first, second and third and later parities) as fixed effects. Composite genotypes with less than nine individuals were excluded from the statistical analysis. If more than two groups were compared, the Bonferroni test was used for multiple testing. The values were considered significant at $p<0.05$ and presented as least squares means. 


\section{Results}

\subsection{Gene Frequency and Composite Genotypes}

Table 1 shows the allelic and genotypic frequencies at CSN1S1, CSN2 and CSN3. The Agerolese population was found to be polymorphic at $\alpha_{\mathrm{s} 1}$-casein encoding locus: in particular, 61 individuals out of 84 were genotyped as BB; 22 as BC and only one cow was homozygous CC. The frequencies of $\mathrm{B}$ and $\mathrm{C}$ alleles were 0.857 and 0.143 , respectively. The expected genotype frequencies, which were calculated according to the Hardy-Weinberg equilibrium, were $73.40 \%$ (BB), $24.64 \%$ (BC), and $1.96 \%$ (CC). The calculated $\chi^{2}$ value was 0.35 (d.f. = 1), indicating Hardy-Weinberg equilibrium in the population $(p=0.55)$. No carriers of the rare $\mathrm{G}$ allele were detected. As regard CSN2, the most frequent genotypes in the investigated population were $\mathrm{A}^{2} \mathrm{~A}^{2}$ and $\mathrm{A}^{1} \mathrm{~A}^{2}(48.8 \%$ and $35.71 \%$, respectively), which were followed by $\mathrm{A}^{1} \mathrm{~A}^{1}$ and $\mathrm{A}^{1} \mathrm{~B}$ (9.53\% and 5.95\%, respectively). The allele frequencies at CSN2 locus were 0.303 (allele $\mathrm{A}^{1}$ ), 0.667 (allele $\mathrm{A}^{2}$ ) and 0.030 (allele B). The comparison between observed and expected genotype frequencies revealed no Hardy-Weinberg equilibrium in the population for this locus $\left(\chi^{2}=12.23 ; p<0.01\right.$; d.f. $\left.=3\right)$. As regard CSN3 locus, 54 Agerolese cows $(64.29 \%)$ were genotyped as $\mathrm{AB}, 23(27.38 \%)$ as $\mathrm{BB}$ and $7(8.33 \%)$ as $\mathrm{AA}$. Thus, the allelic frequencies were 0.405 and 0.595 for $\mathrm{A}$ and $\mathrm{B}$ alleles, respectively. The distribution of genotypes deviated significantly from Hardy-Weinberg expectations $\left(\chi^{2}=9.05 ; p<0.01\right.$; d.f. $\left.=1\right)$.

Table 2 also illustrates the calculated values of the genetic indices, such as $\mathrm{Ho}, \mathrm{He}, \mathrm{Ne}, \mathrm{PIC}$ and FIS for the considered loci. FIS is a measurement of the deviation of genotypic frequencies from panmictic frequencies in terms of heterozygous deficiency or excess. Negative FIS values indicate heterozygote excess, while positive values indicate heterozygote deficiency when compared with Hardy-Weinberg equilibrium expectations. In the Agerolese breed, an excess of heterozygosity at CSN3 locus was found (FIS $=-0.334$ ). PIC is a parameter indicative of the degree of informativeness of a certain marker. The PIC value may range from 0 to 1 . In the Agerolese population, PIC values were 0.215, 0.455 and 0.366 for CSN1S1, CSN2 and CSN3, respectively. According to the classification of PIC (low polymorphism if the PIC value $<0.25$, median if $0.25<$ PIC value $<0.50$ and high if the PIC value $>$ 0.50), the examined population seemed to have a low genetic diversity at CSN1S1 locus; CSN2 and CSN3 loci result more informative showing an intermediate polymorphism level. These results were also confirmed based on the calculated Ne values, which indicated a good level of genetic variability in this breed.

As regard the composite genotypes in the analysed Agerolese cows, 19 different combinations have been identified (Supplementary Table S2). 
Table 1. Observed and expected numbers and percentages (in brackets) of genotypes at CSN1S1, CSN2 and CSN3 loci, allele frequencies and Hardy-Weinberg Equilibrium (HWE) in the sample of Agerolese cows.

\begin{tabular}{|c|c|c|c|c|c|c|c|c|c|c|c|}
\hline \multirow[t]{2}{*}{ Casein Locus } & & \multicolumn{6}{|c|}{ Genotype Frequency } & \multicolumn{3}{|c|}{ Allele Frequency } & \multirow{2}{*}{$\begin{array}{c}x^{2} \\
\text { HWE }\end{array}$} \\
\hline & & BB & BC & $\mathrm{CC}$ & & & & B & $\mathrm{C}$ & & \\
\hline \multirow{2}{*}{ CSN1S1 } & Obs. & $\begin{array}{c}61 \\
(72.62 \%)\end{array}$ & $\begin{array}{c}22 \\
(26.19 \%)\end{array}$ & $\begin{array}{c}1 \\
(1.19 \%)\end{array}$ & & & & 0.857 & 0.143 & & \multirow{2}{*}{$\begin{array}{c}0.35 \\
p=0.55 \\
(\text { d.f. }=1)\end{array}$} \\
\hline & Exp. & $\begin{array}{c}61.65 \\
(73.40 \%)\end{array}$ & $\begin{array}{c}20.70 \\
(24.64 \%)\end{array}$ & $\begin{array}{c}1.65 \\
(1.96 \%)\end{array}$ & & & & & & & \\
\hline \multirow{3}{*}{ CSN2 } & & A1A1 & A1A2 & $\mathrm{A} 2 \mathrm{~A} 2$ & $\mathrm{~A}^{1} \mathrm{~B}$ & $\mathrm{~A}^{2} \mathrm{~B}$ & BB & A1 & A2 & $\mathrm{B}$ & \\
\hline & Obs. & $\begin{array}{c}8 \\
(9.53 \%)\end{array}$ & $\begin{array}{c}30 \\
(35.71 \%)\end{array}$ & $\begin{array}{c}41 \\
(48.8 \%)\end{array}$ & $\begin{array}{c}5 \\
(5.95 \%)\end{array}$ & - & - & \multirow[t]{2}{*}{0.303} & \multirow[t]{2}{*}{0.667} & 0.030 & \multirow{2}{*}{$\begin{array}{c}12.23 \\
p<0.01 \\
(\text { d.f. }=3)\end{array}$} \\
\hline & Exp. & $\begin{array}{c}7.64 \\
(9.10 \%)\end{array}$ & $\begin{array}{c}34.20 \\
(40.71 \%)\end{array}$ & $\begin{array}{c}37.22 \\
(44.31 \%)\end{array}$ & $\begin{array}{c}1.53 \\
(1.82 \%)\end{array}$ & $\begin{array}{c}3.35 \\
(3.99 \%)\end{array}$ & $\begin{array}{c}0.06 \\
(0.07 \%)\end{array}$ & & & & \\
\hline \multirow{3}{*}{ CSN3 } & & AA & $\mathrm{AB}$ & BB & & & & A & B & & \\
\hline & Obs. & $\begin{array}{c}7 \\
(8.33 \%)\end{array}$ & $\begin{array}{c}54 \\
(64.29 \%)\end{array}$ & $\begin{array}{c}23 \\
(27.38 \%)\end{array}$ & & & & 0.405 & 0.595 & & \multirow{2}{*}{$\begin{array}{c}9.05 \\
p<0.01 \\
(\text { d.f. }=1)\end{array}$} \\
\hline & Exp. & $\begin{array}{c}13.64 \\
(16.24 \%)\end{array}$ & $\begin{array}{c}40.72 \\
(48.48 \%)\end{array}$ & $\begin{array}{c}29.64 \\
(35.28 \%)\end{array}$ & & & & & & & \\
\hline
\end{tabular}


Table 2. Population genetic indices for the three considered loci in the sample of Agerolese cows.

\begin{tabular}{lccc}
\hline \multicolumn{1}{c}{ Parameter } & CSN1S1 & CSN2 & CSN3 \\
\hline Gene homozygosity (Ho) & 0.738 & 0.583 & 0.357 \\
Gene heterozygosity (He) & 0.262 & 0.417 & 0.643 \\
Effective allele number (Ne) & 1.324 & 1.861 & 1.930 \\
Polymorphism Information Content (PIC) & 0.215 & 0.455 & 0.366 \\
Fixation Index (FIS) & -0.069 & 0.099 & -0.334 \\
\hline
\end{tabular}

\subsection{Analysis of Milk Samples}

The chemical composition and MCP values (Mean and SD) of the Agerolese cattle milk according to the genotypes at CSN1S1, CSN2 and CSN3 loci are shown in Table 3. None of the analysed milk samples was non-coagulating.

Regarding CSN1S1, the genotype BB showed a statistically significant higher fat content $(3.74 \pm 0.06)$ and lower $k_{20}(6.03 \pm 0.16)$ than the genotype BC $(3.48 \pm 0.15 ; 7.75 \pm 0.41)$. However, since the BC genotype carriers found within this work are very few $(n=4)$, and no one showed a CC genotype on CSN3, it was not possible to establish with certainty the effect of $B C$ genotype on milk production traits in Agerolese cattle. As regard to CSN2, the $\mathrm{A}^{2} \mathrm{~A}^{2}$ genotype showed a statistically significant higher content of protein, total solids and solid-non-fat $(3.49 \pm 0.06 ; 12.73 \pm 0.14 ; 8.97 \pm 0.06$ respectively) than the $\mathrm{A}^{1} \mathrm{~A}^{1}$ genotype $(3.21 \pm 0.11 ; 12.01 \pm 0.28 ; 8.64 \pm 0.12) . \mathrm{A}^{1} \mathrm{~A}^{2}$ genotype showed intermediate values for the same parameters $(3.43 \pm 0.05 ; 12.72 \pm 0.13 ; 8.90 \pm 0.05)$. This is in line with previous studies [37]. A similar condition occurred for MCP; in fact, RCT and $\mathrm{k}_{20}$ were faster in a statistically significant way for the $\mathrm{A}^{2} \mathrm{~A}^{2}$ genotype and $\mathrm{a}_{30}$ value was higher $(13.50 \pm 0.52 ; 5.76 \pm 0.25 ; 24.93 \pm 1.10$, respectively). Contrary to prior research results $[18,38]$, the $\mathrm{A}^{2} \mathrm{~A}^{2}$ genotype in Agerolese cattle was associated with better MCP values. Finally, a statistically significant higher fat content $(3.76 \pm 0.09$ vs. $3.56 \pm 0.07)$ and shorter curd firming time $\left(\mathrm{k}_{20}\right)(5.81 \pm 0.25$ vs. $6.40 \pm 0.20)$ were observed in $B B$ rather than $A B$ genotype at CSN3. These findings are in agreement with previously studies [18].

Considering the effects of the composite genotypes observed by the three loci analyzed on milk chemical composition and MCP values (Table 4), $\mathrm{BBA}^{1} \mathrm{~A}^{2} \mathrm{AB}$ composite genotype showed a statistically significant higher fat content $(3.93 \pm 0.10)$ than the other ones, while for $\mathrm{BBA}^{1} \mathrm{~A}^{2} \mathrm{BB}$ composite genotype there was a statistically increased lactose content (4.77 \pm 0.07$)$. Regarding the protein content, it was similar amongst the four composite genotypes analysed. No statistically significant differences were observed for all the other investigated chemical parameters. 
Table 3. Chemical composition (g/100 g) and MCP of Agerolese cattle milk according to the genotype at CSN1S1, CSN2 and CSN3.

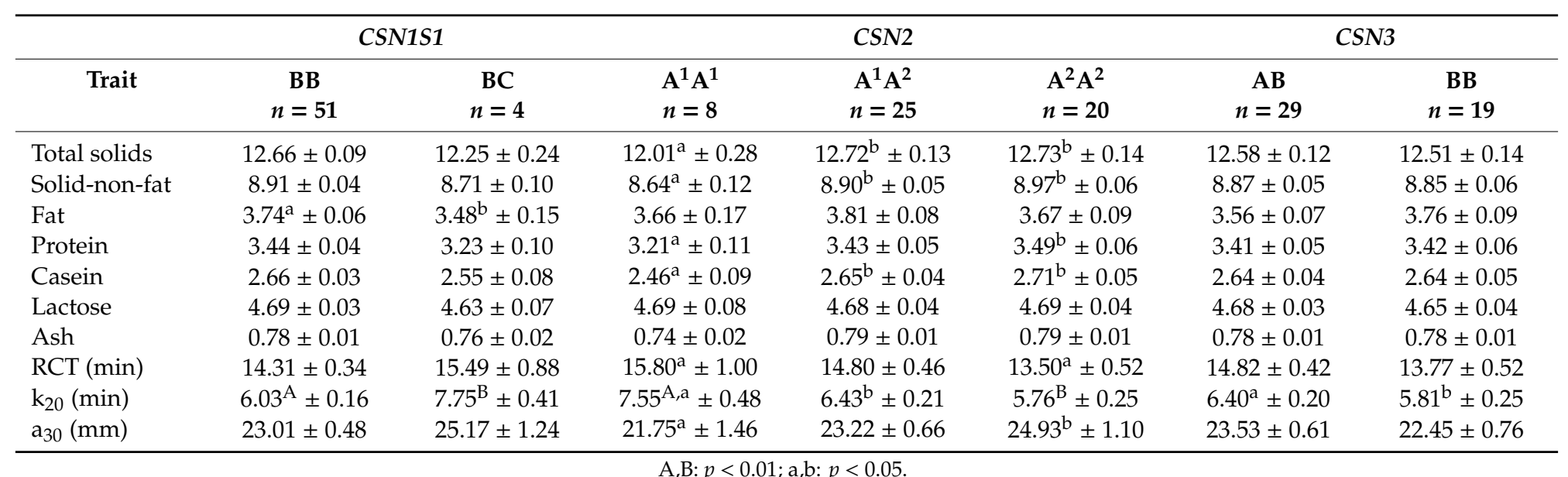

A,B: $p<0.01 ; \mathrm{a}, \mathrm{b}: p<0.05$ 
Table 4. Chemical composition (g/100 g) and MCP of Agerolese cattle milk according to the composite genotype.

\begin{tabular}{|c|c|c|c|c|c|c|c|c|c|c|c|c|}
\hline \multirow{2}{*}{$\begin{array}{c}\text { Trait } \\
\text { Total solids }\end{array}$} & \multicolumn{3}{|c|}{$\begin{array}{c}\mathrm{BBA}^{1} \mathrm{~A}^{2} \mathrm{AB} \\
n=16\end{array}$} & \multicolumn{3}{|c|}{$\begin{array}{c}\mathrm{BBA}^{1} \mathrm{~A}^{2} \mathrm{BB} \\
n=9\end{array}$} & \multicolumn{3}{|c|}{$\begin{array}{c}\mathrm{BBA}^{2} \mathrm{~A}^{2} \mathrm{AB} \\
n=9\end{array}$} & \multicolumn{3}{|c|}{$\begin{array}{c}\mathrm{BBA}^{2} \mathrm{~A}^{2} \mathrm{BB} \\
n=10\end{array}$} \\
\hline & 12.70 & \pm & 0.16 & 12.66 & \pm & 0.21 & 12.49 & \pm & 0.21 & 12.50 & \pm & 0.20 \\
\hline Solids-non-fat & 8.82 & \pm & 0.07 & 8.97 & \pm & 0.09 & $9.03^{\mathrm{a}}$ & \pm & 0.09 & $8.78^{b}$ & \pm & 0.09 \\
\hline Fat & $3.93^{\mathrm{A}, \mathrm{a}}$ & \pm & 0.10 & $3.61^{\mathrm{b}}$ & \pm & 0.13 & $3.40^{\mathrm{B}}$ & \pm & 0.13 & $3.62^{\mathrm{b}}$ & \pm & 0.12 \\
\hline Protein & 3.40 & \pm & 0.07 & 3.43 & \pm & 0.09 & 3.48 & \pm & 0.09 & 3.43 & \pm & 0.08 \\
\hline Casein & 2.62 & \pm & 0.05 & 2.67 & \pm & 0.07 & 2.72 & \pm & 0.07 & 2.64 & \pm & 0.06 \\
\hline Lactose & 4.62 & \pm & 0.05 & $4.77^{\mathrm{a}}$ & \pm & 0.07 & $4.74^{\mathrm{a}}$ & \pm & 0.07 & $4.54^{\mathrm{b}}$ & \pm & 0.06 \\
\hline Ash & 0.79 & \pm & 0.02 & 0.77 & \pm & 0.02 & 0.80 & \pm & 0.02 & 0.80 & \pm & 0.02 \\
\hline RCT (min) & $14.94^{\mathrm{a}}$ & \pm & 0.64 & 14.08 & \pm & 0.85 & 14.84 & \pm & 0.85 & $12.62^{\mathrm{b}}$ & \pm & 0.81 \\
\hline $\mathrm{k}_{20}(\mathrm{~min})$ & $6.65^{\mathrm{a}}$ & \pm & 0.29 & 5.80 & \pm & 0.39 & $5.40^{\mathrm{b}}$ & \pm & 0.39 & 5.84 & \pm & 0.37 \\
\hline $\mathrm{a}_{30}(\mathrm{~mm})$ & 23.51 & \pm & 0.87 & 21.24 & \pm & 1.16 & 23.35 & \pm & 1.16 & 23.72 & \pm & 1.10 \\
\hline
\end{tabular}

\section{Discussion}

The analysis of polymorphisms of genes associated to productive traits in a livestock breed is the first step necessary for the improvement of its profitability. It should not be forgotten that often, in the same species, with same environmental effects, as the breeds varies, a certain level of productivity can be associated with different polymorphisms in the same genes or with completely different genes $[18,38,39]$. This is the reason why we need not only to verify the genotype of a livestock breed of interest but also to correlate it with productions. Native breeds are of great interest because they are important reservoirs of genetic variability, which may be targeted by conservation efforts. Moreover, they might possess unique genetic variation that can affect the milk composition and quality, potentially resulting in distinct milk characteristics that could be exploited in niche dairy products [40]. In this study, 84 Agerolese cattle, representing about $30 \%$ of the entire population ( 285 animals enrolled in the Birth Register) have been analysed for casein composite genotypes and for MCPs.

Genotyping results for the three casein genes analysed showed that in Agerolese cattle are spread only the most common alleles of these genes; interestingly 19 different composite genotypes have been observed indicating a good variability at this level. According to the electrophoretic patterns (UTLIEF) of the milk caseins observed in all the analysed animals, there are no new variants to report in this breed. Analysing CSN1S1 gene, the alleles found and their frequencies confirmed what has been previously observed in other cattle breeds, namely that $C$ allele is not common in Bos taurus, except for few breeds like Jersey, Guernsey, Normande, Italian Brown, Reggiana, Modenese and Normande [41]. In particular, in Jersey its frequency is very high and it might indicate a positive effect on fat and protein content [42]. This does not occur in Agerolese cattle in which milk from heterozygous individuals showed a lower content of both nutrients (Table 2) when compared with homozygous BB animals. The very low number of $\mathrm{CC}$ animals in the sample analysed does not allow stating definitively the effects of CSN1S1 C variant in Agerolese cattle milk productions. Interestingly, the allele frequencies were the same observed in Brown Swiss [42], which contributed to the constitution of current Agerolese cattle.

As regard CSN2, FIS value indicates a heterozygote deficiency that is due to the greater frequency of $\mathrm{A}^{2}$ allele. This is the preferred protein variant for potentially improving human health and, contrary to what has been observed in other breeds [20], $\mathrm{A}^{2} \mathrm{~A}^{2}$ genotype in Agerolese cattle seems to be associated with better milk parameters, in particular with respect to MCP. Its prevalence in the population may be due to an unintentional selection performed by the breeders, which were mainly interested in milk for cheese production. Moreover, $\beta$-casein protein encoded by $\mathrm{A}^{1}$ allele is considered a risk factor for human ischemic heart disease, arteriosclerosis, Type 1 diabetes, sudden infant death syndrome and autism [43]; thus, Agerolese cattle milk products may have healthy properties which would be interesting to investigate. At CSN3 gene locus, a very low number of animals carry the AA genotype; this is probably due to the worst MCPs that are typically associated with this genotype [37]. Finally, 
the analysis of population indexes upholds what has already been observed in terms of overall genetic variability found in other loci studied in the same breed [2,3].

When considering the number of different composite genotypes found $(n=19)$ a surprisingly high variability is observed. This is even more evident when comparing this data with that of other breeds either native or not like German Black Pied Cattle, Swedish Red, Swedish Mountain and Swedish Red Polled [40,42], Italian Holstein [16], Danish Holstein and Danish Jersey [44]. In fact, if considering composite genotypes deriving from combinations of only the alleles found in Agerolese cattle, not one of them showed to carry so high a number of different composite genotypes. With respect to the frequencies of the composite genotypes $\mathrm{BBA}^{1} \mathrm{~A}^{2} \mathrm{AB}$ and $\mathrm{BBA}^{2} \mathrm{~A}^{2} \mathrm{AB}$ are the most common $(19.05 \%)$, while $\mathrm{BBA}^{1} \mathrm{~A}^{1} \mathrm{AA}$ and $\mathrm{BBA}^{2} \mathrm{~A}^{2} \mathrm{AA}$ are among the least common $(1.19 \%)$. This is congruent with the production address of Agerolese cattle milk, in fact, according to Perna et al. [16], $\mathrm{BBA}^{2} \mathrm{~A}^{2} \mathrm{AB}$ composite genotype is positively associated with a high yield of pasta filata cheese while $\mathrm{BBA}^{1} \mathrm{~A}^{1} \mathrm{AA}$ and $\mathrm{BBA}^{2} \mathrm{~A}^{2} \mathrm{AA}$ are negatively associated to this production.

Fat, protein, casein and lactose content values of Agerolese cattle milk were $3.68 \pm 0.83,3.45 \pm 0.50$, $2.67 \pm 0.41$ and $4.67 \pm 0.36$, respectively. These values are similar to those previously reported by Matassino et al. [45] indicating the absence of population change characteristics in the last twelve years. This is normal considering that the Agerolese population is constituted by a very small number of individuals and no selection for any traits has been carried so far on. This could also explain the normality of the data distribution and the residuals homoscedasticity. In fact, selection pressure may be the reason why in same cases an erosion of the left tail of data distribution may be observed.

Considering MCP values, the best $\mathrm{RCT}$ was observed for milks of $\mathrm{BBA}^{2} \mathrm{~A}^{2} \mathrm{BB}$ composite genotype, while optimal $k_{20}$ value occurred for milks of the $B_{B} A^{2} A^{2} A B$ composite genotype. These findings are in agreement with those reported for the Italian Holstein cow [16].

\section{Conclusions}

The study of gene polymorphisms at loci of productive interest allows to evaluate how a breed is suitable for the productions for which it is reared. The analysis of the allele variants of casein genes in the Agerolese cattle shows a low genetic variability at CSN1S1, CSN2 and CSN3. Among the genotypes identified, the CSN2 $\mathrm{A}^{2} \mathrm{~A}^{2}$ is the one associated with better milk characteristics meaning that selection plans with the aim to improve productions in this breed are conceivable. In particular, the wide spread of the $\mathrm{A}^{2}$ variant in the population allows to plan future studies aimed to increase the number of the analysed animals to confirm these results and at evaluating the effects of this variant on the quality of the Provolone del Monaco PDO cheese from a nutraceutical point of view.

Despite the low variability found in all the loci when considered alone, a high variability of the composite genotypes $(n=19)$ has been observed, with a prevalence of those $\left(\mathrm{BBA}^{1} \mathrm{~A}^{2} \mathrm{AB}\right.$ and $\left.B B A^{2} A^{2} A B\right)$ positively associated with the production of milk addressed to cheese manufacture and in particular, to the pasta filata type. These findings support the hypothesis that Agerolese Cattle is an important reservoir of genetic variability the conservation of which today represents one of the aims pursued worldwide in the zootechnical field. Moreover, these data underline the importance of implementing plans that encourage their rearing throughout the territory, limiting the erosion process it is undergoing.

Supplementary Materials: The following are available online at http://www.mdpi.com/2076-2615/10/5/892/s1. Supplementary Figure S1. The figure shows the 13 most representative electrophoretic profiles of 84 individual milk samples analysed. On the top of the lane is reported the genotype of CSN1S1. The arrows highlight typical bands of main variants of CSN2 ( $\mathrm{A}_{1}, \mathrm{~A}_{2}$ and $\mathrm{B}$ variants) and CSN3 (A and B variants). Supplementary Table S1. Oligonucleotide primers sequence and positions. Supplementary Table S2. Frequencies of CSN1S1, CSN2 and CSN3 composite genotypes.

Author Contributions: Conceptualization: F.C. and S.A.; methodology: F.C., S.A., A.S. and G.C.; formal analysis: E.D., S.C., A.F. and G.G.; resources: V.P. and A.S.; data curation: F.C., S.A. and M.S.; writing-original draft preparation: S.A., A.F., S.C. and M.S.; writing—review and editing: F.C., V.P, A.S. and G.C.; supervision: V.P. and F.C. All authors have read and agreed to the published version of the manuscript. 
Funding: This research was funded by Consorzio di tutela del Provolone del Monaco DOP and by AGER 2 Project under grant $n$. 2017-1130.

Acknowledgments: The authors thank Gianfranco Novi for his technical assistance.

Conflicts of Interest: The authors declare no conflict of interest.

\section{References}

1. Peretti, V.; Ciotola, F.; Iannuzzi, L. Characterization, conservation and sustainability of endangered animal breeds in Campania (Southern Italy). Nat. Sci. 2013, 5, 1-9. [CrossRef]

2. Selvaggi, M.; Carbonara, C.; Ciotola, F.; Albarella, S.; Aiudi, G.; Tufarelli, V.; Dario, C. Determination of a possible relationship between a single nucleotide polymorphism (SNP) in the promoter region of the SIRT1 gene and production and reproduction traits in the Agerolese cattle breed. Arch. Anim. Breed. 2019, 62, 107-112. [CrossRef]

3. Selvaggi, M.; Albarella, S.; Dario, C.; Peretti, V.; Ciotola, F. Association of STAT5A gene variants with milk production traits in agerolese cattle. Biochem. Genet. 2017, 5555, 158-167. [CrossRef]

4. Dario, C.; Dario, M.; Ciotola, F.; Peretti, V.; Carnicella, D.; Selvaggi, M. Analysis of STAT5A/Aval gene polymorphism in four Italian cattle breeds. Biochem. Genet. 2009, 47, 671-679. [CrossRef]

5. Dario, C.; Selvaggi, M.; Carnicella, D.; Bufano, G. STAT5A/AvaI polymorphism in Podolica bulls and its effect on growth performance traits. Livest. Sci. 2009, 123, 83-87. [CrossRef]

6. Ciotola, F.; Peretti, V.; Di Meo, G.P.; Perucatti, A.; Iannuzzi, L.; Barbieri, V. Sister chromatid exchanges (SCE) in the cattle popolation Agerolese. Vet. Res. Commun. 2005, 29, 359-361. [CrossRef]

7. Ciotola, F.; Albarella, S.; Liotta, L.; Contessa, A.; Di Meo, G.P.; Barbieri, V.; Peretti, V. Native cattle breeds of Southern Italy: Karyological profile. Ital. J. Anim. Sci. 2009, 8, 54-56. [CrossRef]

8. Rando, A.; Di Gregorio, P.; Ramunno, L.; Mariani, P.; Fiorella, A.; Senese, C.; Marletta, D.; Masina, P. Characterization of the CSN1AG allele of the bovine alpha s1-casein locus by the insertion of a relict of a long interspersed element. J. Dairy Sci. 1998, 81, 1735-1742. [CrossRef]

9. Jõudu, I.; Henno, M.; Värv, S.; Kaart, T.; Kärt, O.; Kalamees, K. Milk protein genotypes and milk coagulation properties of Estonian native cattle. Agric. Food Sci. 2007, 16, 222-231. [CrossRef]

10. Farrell, H.M.J.; Jimenez-Flores, R.; Bleck, G.T.; Brown, E.M.; Butler, J.E.; Creamer, L.K.; Hicks, C.L.; Hollar, C.M.; Ng-Kwai-Hang, K.F.; Swaisgood, H.E.; et al. Nomenclature of the proteins of cows' milk-sixth revision. J. Dairy Sci. 2004, 87, 1641-1674. [CrossRef]

11. Massella, E.; Piva, S.; Giacometti, F.; Liuzzo, G.; Zambrini, A.V.; Serraino, A. Evaluation of bovine beta casein polymorphism in two dairy farms located in northern Italy. Ital. J. Food Saf. 2017, 6, 6904. [CrossRef]

12. Dinc, H.; Ozkan, E.; Koban, E.; Togan, I. Beta-casein A1/A2, kappa-casein and beta-lactoglobulin polymorphisms in Turkish cattle breeds. Archiv. Tierzucht. 2013, 56, 650-657. [CrossRef]

13. Ketto, I.A.; Knutsen, T.M.; Oyaas, J.; Heringstad, B.; Adnoy, T.; Devold, T.G.; Skeie, S.B. Effects of milk protein polymorphism and composition, casein micelle size and salt distribution on the milk coagulation properties in Norwegian Red cattle. Int. Dairy J. 2017, 70, 55-64. [CrossRef]

14. Schaar, J. Effects of $\mathrm{k}$-casein genetic variants and lactation number on the renneting properties of individual milks. J. Dairy Res. 1984, 51, 397-406. [CrossRef]

15. Jõudu, I.; Henno, M.; Kaart, T.; Püssa, T.; Kärt, O. The effect of milk protein contents on the rennet coagulation properties of milk from individual dairy cows. Int. Dairy J. 2008, 18, 964-967. [CrossRef]

16. Perna, A.; Intaglietta, I.; Gambacorta, E.; Simonetti, A. The influence of casein haplotype on quality, coagulation, and yield traits of milk from Italian Holstein cows. J. Dairy Sci. 2016, 99, 3288-3294. [CrossRef]

17. Franzoi, M.; Niero, G.; Penasa, M.; De Marchi, M. Development of infrared prediction models for diffusible and micellar minerals in bovine milk. Animals 2019, 9, 430. [CrossRef]

18. Bittante, G.; Penasa, M.; Cecchinato, A. Genetics and modeling of milk coagulation properties. J. Dairy Sci. 2012, 95, 6843-6870. [CrossRef]

19. Amalfitano, N.; Cipolat-Gotet, C.; Cecchinato, A.; Malacarne, M.; Summer, A.; Bittante, G. Milk protein fractions strongly affect the patterns of coagulation, curd firming, and syneresis. J. Dairy Sci. 2019, 102, 2903-2917. [CrossRef] 
20. Heck, J.M.L.; Schennink, A.; Van Valenberg, H.J.F.; Bovenhuis, H.; Visker, M.H.P.W.; Van Arendonk, J.A.M.; Van Hooijdonk, A.C.M. Effects of milk protein variants on the protein composition of bovine milk. J. Dairy Sci. 2009, 92, 1192-1202. [CrossRef]

21. Caroli, A.; Rizzi, R.; Lühken, G.; Erhardt, G. Short communication: Milk protein genetic variation and casein haplotype structure in the Original Pinzgauer cattle. J. Dairy Sci. 2010, 93, 1260-1265. [CrossRef]

22. Braunschweig, M.; Hagger, C.; Stranzinger, G.; Puhan, Z. Associations between casein haplotypes and milk production traits of Swiss Brown cattle. J. Dairy Sci. 2000, 83, 1387-1395. [CrossRef]

23. Bonfatti, V.; Di Martino, G.; Cecchinato, A.; Degano, L.; Carnier, P. Effects of beta-kappa-casein (CSN2-CSN3) haplotypes, beta-lactoglobulin (BLG) genotypes, and detailed protein composition on coagulation properties of individual milk of Simmental cows. J. Dairy Sci. 2010, 93, 3809-3817. [CrossRef]

24. Aschaffenburg, R.; Drewry, J. New procedure for the routine determination of the various non-casein proteins of milk. In Proceedings of the 15th International Dairy Congress, London, UK, 3-29 July 1959; pp. 1631-1637.

25. Neuhoff, V.; Arold, N.; Taube, D.; Ehrhardt, W. Improved staining of proteins in polyacrylamide gels including isoelectric focusing gels with clear background at nanogram sensitivity using Coomassie Brilliant Blue G-250 and R-250. Electrophoresis 1988, 9, 255-262. [CrossRef]

26. Mitra, A.; Schlee, P.; Krause, I.; Blusch, J.; Werner, T.; Balakrishnan, C.R.; Pirchner, F. Kappa-casein polymorphisms in Indian dairy cattle and buffalo: A new genetic variant in buffalo. Anim. Biotechnol. 1998, 9, 81-87. [CrossRef]

27. Ren, D.X.; Miao, S.Y.; Chen, Y.L.; Zou, C.X.; Liang, X.W.; Liu, J.X. Genotyping of the k-caseinand $\beta$-lactoglobulin genes in Chinese Holstein, Jersey and water buffalo byPCR-RFLP. J. Genet. 2011, 19, e1-e5.

28. Rando, A.; Di Gregorio, P.; Ramunno, L.; Mariani, P.; Fiorella, A.; Senese, C.; Marletta, D.; Masina, P. Erratum in: Characterization of the CSN1AG allele of the bovine $\alpha$ s1-casein locus by the insertion of a relict of a long interspersed element. J. Dairy Sci. 1998, 81, 1735-1742. J. Dairy Sci. 1999, 82, 648.

29. De Marchi, M.; Penasa, M.; Tiezzi, F.; Toffanin, V.; Cassandro, M. Prediction of milk coagulation properties by Fourier transform mid-infrared spectroscopy (FTMIR) for genetic purposes, herd management and dairy profitability. In Proceedings of the 38th International Committee for Animal Recording (ICAR) Meeting, Cork, Ireland, 28 May-1 June 2012; Available online: http://www.icar.org/Cork_2012/Manuscripts/Published/ Cassandro.pdf.

30. De Marchi, M.; Toffanin, V.; Cassandro, M.; Penasa, M. Prediction of coagulating and noncoagulating milk samples using mid-infrared spectroscopy. J. Dairy Sci. 2013, 96, 4707-4715. [CrossRef]

31. Falconer, D.S.; Mackay, T.F.C. Introduction to Quantitative Genetics, 4th ed.; Longman Group Ltd.: Essex, UK, 1996.

32. Yeh, F.C.; Yang, R.; Boyle, T.J.; Ye, Z.; Xiyan, J.M. Pop-Gene32, Microsoft Windows-Based Freeware for Population Genetic Analysis; Version 1.32; Molecular Biology and Biotechnology Centre, University of Alberta: Edmonton, AB, Canada, 2000.

33. Botstein, D.; White, R.L.; Skalnick, M.H.; Davies, R.W. Construction of a genetic linkage map in man using restriction fragment length polymorphisms. Am. J. Hum. Genet. 1980, 32, 314-331.

34. Shapiro, S.S.; Wilk, M.B. An analysis of variance test for normality (complete samples). Biometrika 1965, 52, 591-611. [CrossRef]

35. Levene, H. Robust tests for the equality of variance. In Contributions to Probability and Statistics: Essays in Honor of Harold Hotelling; Olkin, I., Ghurye, S.G., Hoeffding, W., Madow, W.G., Mann, H.B., Eds.; Stanford University Press: Palo Alto, CA, USA, 1960; pp. 278-292.

36. The [output/code/data analysis] for this paper was generated using SAS software. Copyright; SAS Institute Inc; SAS and all other SAS Institute Inc. product or service names are registered trademarks or trademarks of SAS Institute Inc.; Cary, NC, USA.

37. Caroli, M.; Chessa, S.; Erhardt, G.J. Milk protein polymorphisms in cattle: Effect on animal breeding and human nutrition. J. Dairy Sci. 2009, 92, 5335-5352. [CrossRef] [PubMed]

38. Day, L.; Williams, R.P.W.; Otter, D.; Augustin, M.A. Casein polymorphism heterogeneity influences casein micelle size in milk of individual cows. J. Dairy Sci. 2015, 98, 3633-3644. [CrossRef] [PubMed]

39. Albarella, S.; Ciotola, F.; Selvaggi, M.; Dario, C.; Licciardi, S.; Scopino, G.; Frate, D.; Peretti, V. Analysis of major fecundity genes in autochthonous Laticauda and Bagnolese sheep breeds. Small Rumin. Res. 2015, 133, 118-122. [CrossRef] 
40. Poulsen, N.A.; Glantz, M.; Rosengaard, A.K.; Paulsson, M.; Larsen, L.B. Comparison of milk protein composition and rennet coagulation properties in native Swedish dairy cow breeds and high-yielding Swedish Red cows. J. Dairy Sci. 2017, 100, 8722-8734. [CrossRef]

41. Formaggioni, P.; Summer, A.; Malacarne, M.; Mariani, P. Milk protein polymorphism: Detection and diffusion of the genetic variants in Bos genus. Ann. Fac. Med. Vet. Univ. Parma. 1999, 19, 127-165.

42. Meier, S.; Korkuć, P.; Arends, D.; Brockmann, G.A. DNA Sequence variants and protein haplotypes of casein genes in German Black Pied cattle (DSN). Front. Genet. 2019, 10, 1129. [CrossRef]

43. Cieślińska, A.; Fiedorowicz, E.; Zwierzchowski, G.; Kordulewska, N.; Jarmołowska, B.; Kostyra, E. Genetic polymorphism of $\beta$-Casein gene in Polish Red Cattle-Preliminary study of A1 and A2 frequency in genetic conservation herd. Animals 2019, 9, 377. [CrossRef]

44. Gustavsson, F.; Buitenhuis, A.J.; Johansson, M.; Bertelsen, H.P.; Glantz, M.; Poulsen, N.A.; Lindmark Månsson, H.; Stålhammar, H.; Larsen, L.B.; Bendixen, C.; et al. Effects of breed and casein genetic variants on protein profile in milk from Swedish Red, Danish Holstein, and Danish Jersey cows. J. Dairy Sci. 2014, 97, 3866-3877. [CrossRef]

45. Matassino, D.; Barone, C.M.A.; Colatruglio, P.; Fornataro, D.; Occidente, M.; Zullo, A. Milk composition and cheese making properties of the milk obtained from some Italian bovine genetic types. EAAP 2006, 118, 149-151.

(C) 2020 by the authors. Licensee MDPI, Basel, Switzerland. This article is an open access article distributed under the terms and conditions of the Creative Commons Attribution (CC BY) license (http://creativecommons.org/licenses/by/4.0/). 